\title{
Animism and Personal Religion in Southeast Asia
}

\author{
Nathan Porath \\ CESD Chiang Mai University \\ nathanporath@yahoo.co.uk \\ Chayan Vaddhanaphuti \\ RCSD Chiang Mai University \\ ethnet@loxinfo.co.th
}

Kaj Århem and Guido Sprenger, Animism in Southeast Asia. London and New York: Routledge, 2016, 325 Pp. ISBN 9780415713795. Price: G B P 110.00 (hardback); 978131566o288, 27.99 (e-book).

Kees Buijs, Personal Religion and Magic in Mamasa, West Sulawesi. The Search for Powers of Blessing from the Other World of the Gods. Vol. 1. Leiden/Boston: Brill, 2016, viii + 163 pp. ISBN: 9789004326569, price: EUR 75.00 (hardback); 9789o04326576, 75.0o (e-book).

During the last decade of the twentieth century the term animism was unexpectedly reintroduced within new overlapping theoretical models by authors working in various parts of the world (South America, India, the Circumpolar region). These models revitalized the concept of 'animism', originally developed by Edward Burnet Tylor (1871) in novel directions without any of the negative and evolutionary connotations originally attached to it. In the 'New Animism' model, animism is understood to be a relational ontology in which the environment is teeming with diverse agents, socially interacting with each other (Bird-David 1999, 2006, Ingold 2000 chapter 7, 2006, Hornborg 2006:27, Descola 2013). These agents or subjects share what Descola (2006) calls an interiority', which in other academic discourses is sometimes called soul/spirit. A further concept developed by Viveiros de Castro is 'perspectivism' (De Castro 1999, 2004, 2012). In this related model of animist-ontology, different species have their own perspective or nature. Through this perspective the species sees itself in the way humans see themselves, and see humans in the way humans see animals (De Castro 1998). The New Animism is also seen by some (Ingold 2006, Hornborg 2006) to provide a new mode of relational thinking about the

(C) NATHAN PORATH AND CHAYAN VADDHANAPHUTI, 2017 DOI: 10.1163/22134379-17304005 This is an open access article distributed under the terms of the prevailing CC-BY-NC license 
environment. This line of thought is reflected in Tim Ingold's short theoretical postscript in Animism in Southeast Asia, where he suggests that the 'ism'in animism is suggestive of rigidity and that it would be better to use the term 'animic', which provides a sense of openness within a world that is in process (305).

The new animism (or animic) models have rarely been applied to the Southeast Asian region which has, however, always provided case examples of animism (although see Tsintjilonis 2004). The focus of the two books under review is on human-spirit inter-relations and ritual practices that actualize those relations, and they both provide ethnographic data that allow us to explore the new animism models. Kaj Århem and Guido Sprenger's edited book Animism in Southeast Asia is an attempt by a number of anthropologists at exploring the new animism models in relation to the Southeast Asian region's diverse spirit-beliefs and practices. It focuses on a number of themes, particularly on sacrifice and offerings, as well as landscapes and perspectival inversions. This study is very important for those working on spirit-related topics. Much of the ethnographic data and themes presented in this volume should be familiar to anthropologists working on the region but it is precisely because of this that the book, which offers novel perspectives on these themes, will prove useful.

Kees Buijs' Personal Religion and Magic in Mamasa is a detailed ethnography mainly focusing on different forms of sacrifices and offerings, which the Mamasa Toraja give to the celestial and spirit beings as well as other ritual practices carried out for personal protection and well-being. Buijs' account emerges from an anthropological tradition familiar to those who were trained by Reimar Schefold at Leiden University (during the 199os and the first decade of the millennium). Although Buijs' ethnographic descriptions have general similarities with some of those presented in Århem and Sprenger's book, he ignores the recent debates on animism, which the latter book addresses. Buijs' main theoretical point is to show that the religious and magical thought of the Toraja is rational within the context of the culture that practices it, and in his conclusion he makes a comparison of Toraja thought and practice with the rationality of Science.

In Århem's first of three contributions to Animism in Southeast Asia, entitled 'Southeast Asian Animism in Context', he points out that the new animism model was developed out of ethnographic material drawn from egalitarian hunting societies. However, in Southeast Asia there is an animist social continuum ranging from egalitarian societies, ranked societies, and hierarchical societies. In the more ranked and hierarchical societies, the relationship between 'interiorities' is conceived in more vertical terms. Århem calls this 'vertical animism' all beings are integrated by a principle of asymmetric inter-subjectivity 
(p. 25). He argues that in the newer model of animism a large part of the ranked and hierarchical societies of Southeast Asia, which have always been part of the old animism model's theoretical interests, are excluded (p. 4). Further, Descola's model (2006), which posits four ontologies (animism, totemism, analogism, and naturalism), considers hierarchic ontologies as being more constitutive of analogism (different interiorities, different physicalities) (p. 14). Århem stresses that an ontology of 'shared interiorities' also proliferate in 'analogical universes' (p. 14). Thus, Sprenger, in his ethnographic case example on the relatively more hierarchic Rmeet of Laos (chapter 4), writes of an animist form of graded personhood (subjectivity).

A further case, raised by Århem in the same chapter, is the practice of sacrifice. Descola (2006), in the above mentioned theoretical/ typological work on different ontologies sees this practice as an institution developed within an analogical ontology. But as a number of authors in Animism in Southeast Asia show, as well as Buijs in Personal Religion and Magic, sacrifice in Southeast Asia is clearly associated with spirit-based ontologies. Therefore, the New Model is basically a scaled-down model of Tylor's animism that does not include the more hierarchical societies that practice animism. In his chapter on sacrifice, Århem concludes that Southeast Asian ethnographies challenge Descola's typologies, that the concept of animism should be broadened, and that the concept of analogism should be reduced to cover the more ranked and hierarchical societies (pp. 4, 14). Århem's concluding chapter to the book, entitled 'Southeast Asian Animism: A Dialogue with the Amerindian Perspectivism', and written as a dialogue with the Amerindian material, develops these themes further and tries to show the differences between the animisms of the two regions.

In Guido Sprenger's first of two chapters, the concept of animism is developed in relation to 'exchange', 'accessibility to the senses' and 'hierarchy'. He points out that if in hunting societies spirits take the lives of people and people the lives of spirits, in agricultural animist societies, spirits receive the lives of domesticated animals in sacrifice to prevent them from taking the lives of humans (p. 33). Sprenger also points out that it is through exchange that the alterity of being is produced as the basis of sociality (p. 35). Spirits, as invisible beings, are inaccessible to the senses and diminished accessibility to the senses indicates social distance. In the project of life producing difference, Sprenger argues that rituals of exchange are performed to socialize humans and non-humans (p. 44). This is also Buijs' concern, in Personal Religion and Magic. The Toraja animism entails sacrifices for dewata, celestial and invisible beings, which Buijs calls 'gods' and 'spirits'. These dewata dwell in socially distant realms he calls, following Schefold, 'wilderness'. The important point 
for Buijs is that through sacrificial exchange with beings from the 'wilderness', certain potent forces can be obtained that are necessary for the people's wellbeing. Buijs, again following Schefold, calls these potent forms 'blessings'.

A number of authors in Animism in Southeast Asia show how the ontology of spirits determine decisions concerning the environment and movements in the environment (most notably Nicolas Århem writing on the Katu of highland Vietnam). In her chapter, Monica Janowski explores comparatively what she calls the 'dynamics of the cosmic conversation' among the Kelabit farming communities and Penan hunting and gathering communities of the upper Baram river, Sarawak. She shows their similarities and differences. An important part of these dynamics is what Jon Henrik Ziegler Remme in his chapter on the Ifugao of Northern Luzon, Philippines, refers to as 'onto-practices' that 'actualize' spirits in order to manage relationships with them. Comparably, Buijs, in Personal Religion and Magic refers to the same theme as rituals that 'activate' the spirits. In the main section of his book Buijs focuses on the concept of pairan, which underlies the personal practices of activating (actualising) the spirit realms mainly through sacrifice. In the glossary, he translates this term as 'individual religion, centered in the kitchen at the lalikan (hearth) in the fireplace, where personal offerings are given to the dewata', but in the title of the chapter as 'individual religious responsibility'. He argues that pairan permeates the whole society as a religious responsibility and it is because of pairan that people engage the spirits through rituals of exchange. Buijs is arguing that ritualized relationships with spirits is a personal duty and forms people's personal religion.

One important theme for Buijs that also appears in some of the chapters of Animism in Southeast Asia (notably, Janowski, Kaartinen and Cederroth), concerns power stones. Buijs sees the collection of power stones as an example of personal religion. His chapter on this provides illustrative accounts about the personal use of such stones for protective purposes. In her chapter for Animism in Southeast Asia, Janoswki explains that, for the Kelabit and the Penan, sometimes lalud/ penyukut (spirit) can become hard and take form as special stones. These stones exist as nuggets of power in the environment (p. 196). Likewise, as Buijs explains in his book, among the Toraja of Mamasa they are called balo balo and they provide invulnerability and other powers. These power stones are 'vestiges from the other world of the gods' (p. 103).

One theme that is lacking in both volumes is the experience of spirits through the altered states of consciousness (ritualized or aberrant) as in many instances relationships with spirits bring on the onset of shifts in awareness. There are, however, allusions to it in Animism in Southeast Asia in the discussions relating to Viveiros de Castro's concept of perspectivism and metamor- 
phosis/transformation. In her fascinating chapter on the Chewong of Malaysia, Signe Howell re-analyzes her ethnographic data originally obtained during the late 1970s (Howell 1984), when Animism was an unfashionable concept. Her data comes closest to Viveiros de Castro's perspectivism model. In her own work, she used the term 'relativity in perception'. For the Chewong, she explains, many things have internal ruwai (spirit/soul) and (hot) eyes that see the world from their own perspective. Some individuals have 'cool eyes' which allows them to see the reality of interiorities and through ruwai move between 'species' undetected. Among the Chewong, 'shamans' are people who have cool eyes and who have the power to metamorphose into other beings. In order to prevent the permeation of interiorities, which is dangerous unless one is a shaman, all 'species' have to follow what Howell calls 'cosmo-rules' (prohibitions) that maintain the boundaries between them. Other authors also discuss the perspectivism theme in relation to their own data. As Kenneth Sillander points out in his contribution on the Bentian of Borneo, metamorphosis is a possibility because of the lack of absolute boundaries. In his chapter on animism in Eastern Indonesia Timo Kaartinen quotes Valeri (2000) by giving the example of a perspectival shift of a hunter who was possessed by the hunted animal (p. 23o). Remme also sees the importance of exchange between humans and spirits, and argues further that narratives emerging from these encounters with spirits give shape to the conceptualizing of spirits (p. 146). In 'Impaling Spirits: Three Categories of Ontological Domains in Eastern Indonesia', David Hicks explores the recurring motifs of seven mythic narratives from this region which portrays heroes entering the realms of the spirit-other. All these chapters explore what is sometimes called altered states of consciousness.

A number of authors in Animism in Southeast Asia discuss the tension between the pre-Christian animist beliefs and adopted new transnational religions like Christianity and Islam. Sven Cederroth focuses on the interrelationship between animism and transnational religions among the Wetu Telu of Lombok and shows how the earlier belief system is retained in modified form in Hinduism and Islam, religions which they adopted during later periods. But for many the previous beliefs in spirit might be viewed negatively. For example, Matthew $\mathrm{H}$. Amster argues that the concern with searching for signs of power in the environment in order to determine action and maintain boundaries in a permeable world underlies the Christian Kelabit's view of their Pre-Christian past as having been a life riddled with anxiety. The conversion to Christianity and their placing their faith in Jesus helped them overcome these anxieties. Janowski, referring to a similar problem among the same people, refers to this religious transformation as 'the loss of attention to the flow of power' (p. 197) as now power comes from one main protective Christian source. 
Buijs also explores the tension between the aluk to yolo (the religion of the people who lived in former times) with Christianity, though unfortunately he does not fully integrate his discussion into the ethnography. Based on Buijs' descriptions of pairan for instance, one wonders how much is this concept today influenced by notions drawn from the cultural and religious morality of the Church. Buijs refers to pairan as a form of 'personal devoutness' (p. 5) and later says that through pairan 'people experience a sort of calling' (p. 44). If the Toraja do see pairan in terms of 'individual responsibility' and as 'a kind of calling' then this view of their religious necessity or duty to engage the dewata could be modeled on notions of Christian personal duty.

The two books discussed are important contributions to their subject matter. Animism in Southeast Asia might prove to be a landmark for a new direction in Southeast Asian ethnographies of spirit beliefs (Animism). Personal Religion and Magic in Mamasa, which is also beautifully illustrated with very clear and relevant photographs, will be of interest to scholars working on the Toraja, Sulawesi, religious beliefs and sacrifices.

\section{References}

Bird-David, Nurit (1999). 'Animism' Revisited. Personhood. Environment and Relational Epistemology', Current Anthropology Volume 4o Supplement issue, 17-91

Bird-David, Nurit (2006). 'Animistic epistemology: Why do some hunter-gatherers not depict animals?', Ethnos: Journal of Anthropology, 71:1, 33-50

Descola, Philippe (2006). 'Beyond Nature and Culture', Proceedings of the British Academy Vol. 139: 137-155 DoI:10.5871/bacad/9780197263945.003.00o6

Descola, Philippe (2013). Beyond Nature and Culture. Chicago and London: The University of Chicago Press.

Hornborg, Alf (2006). 'Animism, Fetishism, and Objectivism as Strategies for knowing (or not knowing) the World', Ethnos:Journal of Anthropology, 71:1, 21-32

Howell, Signe (1984). Society and Cosmos, Chewong of Peninsular Malaysia. Oxford University Press.

Ingold, Tim (2000). The Perception of the Environment; Essays on Livelihood, Dwelling and Skill. London: Routledge.

Tsintjilonis Dimitri (2004). "The Flow of Life in Buntao. Southeast Asian Animism: Reconsidered', Bijdragen tot de Taal-, Land —en Volkenkunde, 16o: 4, 425-455

Tylor, Edward B. (1871). Primitive Culture: Researches into the Development of Mythology, Philosophy, Religion, art and Custom. Vol. 1 and 2. London: John Murray, Albemarle Street. 
Valeri, Valero (2000). The Forest of Taboos, Morality, Hunting and Identity among the Hualulu of the Moluccas. Madison wI: The University of Wisconsin press.

Viveiros de Castro, Eduardo (1998). 'Cosmological Deixis and Amerindian Perspectivism', The Journal of the Royal Anthropological Institute, 4: 3, 469-488

Viveiros de Castro, Eduardo (2004). 'Perspectival Anthropology and the Method of Controlled Equivocation Tipit', Journal of the Society for the Anthropology of Lowland South America, 2:1, 3-20

Viveiros de Castro, Eduardo (2012). 'Immanence and Fear Stranger Events and Subjects in Amazonia HAU', Journal of Ethnographic Theory 2:1, 27-43 